\title{
The Joint Working Group between the Roman Catholic Church and the World Council of Churches
}

\author{
Annemarie C. Mayer, Catholic University Leuven, Belgium
}

\begin{abstract}
During 53 years of its 70 years' existence the World Council of Churches (WCC) had a Joint Working Group (JWG) with the Roman Catholic Church (RCC). I would like to seize the opportunity of this $70^{\text {th }}$ anniversary to reflect on the tasks of the JWG. For doing so I shall start by giving a very brief overview over some facts, dates and ciphers. I shall then dwell on the very beginnings of the JWG, how it all came about - and explain some crucial turning points and shifts in its history of more than half a century. The next step will concentrate on some theological highlights of the JWG's work and present the work in progress of the current JWG. One question that logically follows from the very existence of a JWG is that of Roman Catholic membership in the WCC. I shall address this question following the footsteps of the JWG. The concluding reflections on some of the achievements and challenges will once again make it clear what the JWG is and what it is not.
\end{abstract}

\section{Some Facts, Dates and Ciphers to Start with}

18 February, 1965 is the official birthday of the JWG. In its history it so far has held 44 plenary sessions and produced nine official reports plus some 20 theological studies and texts. ${ }^{1}$

It consists of two co-moderators, two co-secretaries, and the ordinary members appointed by both constituencies. While there were initially eight WCC and six RCC members, their number increased in the course of the years to 18 on each side. Yet with the most recent mandate in 2014 it was reduced again to 10 people from each constituency. If I did not miscalculate, during the last 53 years of the JWG's existence, 97 theologians on WCC side and 95 on RCC side have been appointed as its members by the respective parent bodies, which are the WCC and the Pontifical Council for Promoting Christian Unity (PCPCU), or (as it was called before 1988) the Secretariat for Promoting Christian Unity (SPCU). There are members who belong ex officio to the JWG and its executive group (like the Director of Faith and Order, the Deputy

\footnotetext{
1 They are "Joint Worship at Ecumenical Gatherings" (1965), "Ecumenical Dialogue" (1967), "Patterns of Relationship between RCC and WCC" (1969), "Common Witness and Proselytism" (1970), "Catholicity and Apostolicity" (1970), "Future Joint Activities of RCC and WCC" (1973), "WCC and RCC Collaboration" (1974), "Common Witness: A Study Document of the JWG" (1982), "The Church: Local and Universal" (1990), "The Notion of 'Hierarchy of Truths'” (1990), "Ecumenical Formation: Ecumenical Reflection and Suggestions" (1993), "The Challenge of Proselytism and the Calling to Common Witness" (1995), "The Ecumenical Dialogue on Moral Issues: Potential Sources of Common Witness or of Divisions" (1995), "The History of the RCC and WCC Joint Working Group" (1998), "Ecclesiological and Ecumenical Implications of a Common Baptism" (2005), "The Nature and Purpose of Ecumenical Dialogue" (2005), “Inspired by the Same Vision': Roman Catholic Participation in National and Regional Councils of Churches" (2005), "Reception: A Key to Ecumenical Progress" (2012), "Be Renewed in the Spirit: The Spiritual Roots of Ecumenism" (2012), "The Church in the Life of Youth and Youth in the Life of the Church" (2012). It also commissioned F\&O papers like "Towards a Confession of the Common Faith" (F\&O papers no. 100, Geneva 1978).
} 
General Secretary, the head of the Western Section of PCPCU, the Catholic Consultant etc.). The JWG meets once a year, its executive group, consisting of the co-moderators, cosecretaries and the ex officio WCC and PCPCU staff members, meets at least once in between the plenaries, if necessary, more often. Each mandate lasts from one General Assembly of WCC to the next. At the end of each mandate the WCC Central Committee and the PCPCU evaluate the work of the JWG. Each mandate meanwhile starts with the group familiarising itself with the particular structures of the parent bodies in Rome and Geneva and with "building a sense of teamwork and of shared spiritual commitment". ${ }^{2}$ Each plenary meeting of the JWG starts with a sharing of information drawn from the recent experience of the members who come from different parts of the world. The JWG is a merely consultative body, acting as a kind of think-tank, and can only give recommendations to its respective constituencies, helping them to respond to issues emerging on the way to Christian unity today. The JWG is meant to provide the space where to share and discuss important topics affecting the relationship between the WCC and RCC. It is a concrete sign for the structured and sustained relationship between the two parent bodies.

Today the WCC with its 350 member churches represents over 550 million Christians from Orthodox, Anglican and various Protestant backgrounds. The Catholic Church, according to the Annuarium Statisticum Ecclesiae 2016, counts about 1.299 billion members. ${ }^{3}$ It is more than obvious that not every member church and every bishops' conference can send a representative to such a small body as the JWG. Nevertheless, its self-understanding is that it does its work on behalf of all the members of the respective parent bodies.

The very fact that this form of co-operation between the Roman Catholic Church and the World Council of Churches was established and continued for 53 years must in itself be considered as one of the significant achievements of the modern ecumenical movement.

\section{The Prehistory and Beginnings - or: How did it all come about?}

On 15 April 1964 at a small unofficial meeting in Milan, where Cardinal Augustin Bea, then President of SPCU, and the then General Secretary of WCC, Rev. Dr Willem Adolf Visser't Hooft were present, it was agreed that such a thing like a JWG was desirable. It was felt that the time for permanent representatives in Rome and Geneva had not yet come, but close cooperation was indispensable. Therefore a joint group should dedicate itself to sketching out the principles necessary for future cooperation and should address theological questions and practical matters.

By then, though in the middle of the Second Vatican Council, and still before Unitatis Redintegratio had been finished, accepted and promulgated, the WCC and the RCC had already had an interesting and increasingly encouraging history of exchanges.

Looking back at this history, we start with the somewhat less encouraging 'Rhodes incident': In 1959, 11 years after the founding of WCC, a meeting of the Central Committee of the WCC

\footnotetext{
2 PCPCU, Reflections on the Joint Working Group between the Roman Catholic Church and the World Council of Churches (1965-2005), The Ecumenical Review 57/4 (2005) 492-494; 494.

${ }^{3}$ Cf. Presentazione dell'Annuario Pontificio 2018 e dell' "Annuarium Statisticum Ecclesiae" 2016, 13 June 2018; https://press.vatican.va/content/salastampa/it/bollettino/pubblico/2018/06/13/0440/00957.html (accessed 26 June 2018).
} 
took place in Rhodes. Two Catholic priests were present as journalists, Johan Willebrands and Jean-Christophe Dumont. Taking part in activities of the WCC as journalist was the only form of presence that Catholic authorities would allow in those days. Dumont managed to arrange an unofficial friendly meeting with some Orthodox theologians. This private encounter, however, was interpreted by the press and by the leaders of the WCC as an official attempt to draw the Orthodox to the Catholic side and distance them from Geneva. Since it was understood as the two Catholics violating their guest status, this so-called 'Rhodes incident' provoked a very strong reaction from the WCC. This reaction shows the initial mistrust. In consequence a meeting between representatives of WCC and RCC, fixed for October 1959, was cancelled. Although the misunderstandings could be clarified quickly, nevertheless in the following years the question of the effects and the impact, which the Catholic involvement in the quest for Christian unity would have, remained open. From WCC side "[t]he fear was constantly expressed that the Roman Catholic entry into the ecumenical movement might lead to the polarisation of ecumenical efforts, to dialogue with other Churches but not to dialogue in fellowship with other Churches."

In 1961 five observers from the RCC had been sent to the WCC's Third General Assembly in New Delhi; likewise a delegation of RC observers had attended the World Mission Conference in Mexico City in 1963. ${ }^{5}$ In the same year, at the World Conference of Faith and Order in Montreal, the RC biblical scholar Raymond Brown S.S.S. presented one of the keynote papers, entering into a lively exchange with Prof. Ernst Käsemann, his Protestant counterpart. On the other hand, the WCC had sent four observers to the Second Vatican Council, Lukas Vischer and Nikos Nissiotis (full time), along with two part-time observers, Bishop John Sadiq and Prof. Masatoshi Doi.

It became increasingly clear that a JWG as a consultative forum between the WCC and the RCC should come into being. Yet, two institutions like the WCC and the RCC cannot simply start a new JWG, a new joint venture. In July 1964 the Executive Committee of the WCC met in Tutzing, Germany and discussed a possible "Basis of Cooperation with the Roman Catholic Church". Details still had to be fixed, above all during the Third Session of the Council when the WCC observers met twice with the Secretary of SPCU, Bishop Johan Willebrands, and even presented the plan personally to Pope Paul VI. Between 12 and 21 January 1965, the Central Committee of WCC met in Enugu, Nigeria, and proposed the setting up of a joint group to study ways of fostering contact between the RCC and the WCC. It should have a provisional mandate of 5 years. The Enugu Statement by which the Central Committee adopted the proposal of a JWG underlines:

"The World Council of Churches and the Roman Catholic Church are not comparable entities. The World Council of Churches is a fellowship of many churches with different confessional background. The Roman Catholic Church is a single church.

\footnotetext{
${ }^{4}$ Lukas Vischer, "The Activities of the Joint Working Group between the Roman Catholic Church and the World Council of Churches 1965-1969", The Ecumenical Review 22/1 (1970), 36-69; 40.

5 The delegation consisted of Fr Thomas Stransky and Fr Jorge Mejia.
} 
Their cooperation creates therefore special problems. These problems can however best be solved by frank discussion."

Only a few weeks later, on 18 February 1965, during his visit to Geneva, Cardinal Bea communicated the official reply of the Holy See, which was also favourable. ${ }^{7}$ Then, finally, from 22 to 24 May 1965 the first meeting of the JWG could take place in Bossey, near Geneva, under the chairmanship of the two co-moderators, Willem A. Visser't Hooft and Bishop Johan Willebrands. One of the immediate and quite tangible outcomes of this meeting were the materials for the Week of Prayer for Christian Unity, since 1965 now produced jointly. Thus, and this is highly significant, the first fruit of the work of the JWG was not some theoretical reflection, but this enduring contribution to what we today call 'spiritual ecumenism'. By the way, the Week of Prayer advanced in 2004 from the joint production of the materials to completely joint publication. And, "[p]rayer is the oxygen of ecumenism", 8 as Pope Francis stressed on 21 June 2018 at WCC.

The JWG started as an experiment, and actually was meant to have interim character. The daring nature of this experiment becomes clearer if we consider what an effort it is to bring together two bodies which are quite different in their structure and scope, namely a church and a fellowship of churches. This, in the course of the decades, often caused tensions and inconsistencies.

\subsection{The Early Years of the JWG}

Yet during its early years the JWG was extremely productive and efficient: Already in early 1966, after its second plenary session in November 1965, it could present the first official report on its work that had dealt with the nature of ecumenism, ecumenical dialogue, areas of collaboration, Church and society, laity and women, the possibility of a common date of Easter and joint Bible translations. This First Report also contains something like a 'definition' of the JWG as it was conceived by its founders, its first mandate:

"The Joint Working Group was not set up to undertake negotiations. Its work is to be more limited: it is intended to examine possibilities in the field of dialogue and cooperation. Moreover, it has no power to take decisions. Its business is the joint study of problems, and thereafter to report to the competent authorities on both sides.

Its task, both spiritual and pastoral, is to be undertaken in a spirit of prayer, and in the conviction that God is guiding His people. The Group is not limited to settling the technical and administrative aspects of collaboration; it is called on to discern the will of God in the contemporary ecumenical situation." ${ }^{9}$

6 Central Committee of WCC, Statement "Relation between WCC and RCC" January 1965, no. 6, http://www.prounione.urbe.it/dia-int/jwg/doc/e_jwg_statement.html (accessed 26 June 2018).

${ }^{7}$ Cf. "Cardinal Bea and Pastor Boegner meet at World Council”, The Ecumenical Review 17/ 2 (1965), 127-134.

${ }^{8}$ Pope Francis, Address of His Holiness at Ecumenical Meeting at the Ecumenical Centre, Geneva, 21 June 2018 , https://w2.vatican.va/content/francesco/en/speeches/2018/june/documents/papa-francesco_20180621_pellegrina ggio-ginevra.html (accessed 26 June 2018).

9 The Joint Working Group, "First Official Report of the Joint Working Group between the Roman Catholic Church and the World Council of Churches" (1966) no. 1, Information Service 1 (1967/I), 18-33; 18. The first 
- a challenging goal, above all because the First Report concluded that a comparison between the concepts of ecumenism can only be made between churches, not between WCC and RCC: "The task of Ecumenism is not regarded by the two sides in a wholly similar manner." 10 Thus, the asymmetry was stated. Moreover, as an appendix to the First Report, a text on "Joint Worship at Ecumenical Gatherings" was published which underlined: "The participants must be able to experience both the existing oneness in Christ and the difficulties still to be overcome." 11

In May 1967 the Second Report already followed. After the First Report, the work of the JWG had focussed on the nature of dialogue, mixed marriages, proselytism, the work of women and men in the Church and the role of the churches in Aid, Development and Justice. This Second Report asserted that there is but one single ecumenical movement and asked the important question what form the relationship between RCC and WCC should be given "in order to witness to Christ and to serve better the unity which He desires for His Church". ${ }^{12}$ The appendix published three months after the report was a working paper on "Ecumenical Dialogue". ${ }^{13}$

In 1967 for the first time the JWG finished a report before a WCC General Assembly (Uppsala 1968) and sent it to both parent bodies for response. This set the pattern for the coming decennia and actually defined the mandates of this ecumenical body. Ever since then, JWG mandates last from one General Assembly of the WCC to the next.

Of the manifold areas of cooperation I already mentioned common prayer at ecumenical gatherings. Another, very important field were social service activities. The Second Report, therefore, dwelt on the cooperation regarding peace and international social justice, emergency

four Reports are unfortunately not published in Growth in Agreement. Reports and Agreed Statements of Ecumenical Conversations on a World Level, vol. I, ed. Harding Meyer and Lukas Vischer, New York and Geneva: Paulist Press and WCC Press, 1984 (GiA). Only from the Fifth Report onwards are the official reports of the JWG published in Growth in Agreement (vol. II, 821-934). The German edition Dokumente wachsender Übereinstimmung (vol. I, 586-701) is more concise, documenting the first four official reports as well as Towards the Confession of a Common Faith (1980) and Common Witness (1982). Online the JWG texts are available from the WCC website https://www.oikoumene.org/en/resources/documents/commissions/jwg-rcc-wcc/documents-of-the-joint-working -group-between-the-roman-catholic-church-and-the-wcc and the Centro pro Unione website http://www.prounione.urbe.it/dia-int/jwg/e_jwg-info.html. Where possible I shall quote from printed editions of JWG texts in this article.

${ }^{10}$ The Joint Working Group, "First Official Report of the Joint Working Group between the Roman Catholic Church and the World Council of Churches" (1966) no. 2, Information Service 1 (1967/I), 18-33; 18.

11 The Joint Working Group, "First Official Report of the Joint Working Group between the Roman Catholic Church and the World Council of Churches" (1966) Appendix 2: "Joint Worship at Ecumenical Gatherings", Information Service 1 (1967/I), 18-33; 23.

12 The Joint Working Group, "Second Official Report of the Joint Working Group between the Roman Catholic Church and the World Council of Churches" (1967) no. I.8, Information Service 3 (1967/III), 28-35; 29.

13 The Joint Working Group, "Second Official Report of the Joint Working Group between the Roman Catholic Church and the World Council of Churches" (1967) Appendix: "Ecumenical Dialogue", Information Service 3 (1967/III), 32-35. 
relief and medical aid. ${ }^{14}$ Long-term efforts should be made, but also immediate action should be taken like against the famine in India that in those days was threatening. ${ }^{15}$ In June 1967, still in the wake of the "Pastoral Constitution Gaudium et Spes on the Church in the Modern World" and the Encyclical "Populorum Progressio", two delegations met in Geneva under the chairmanship of Mgr. Joseph Gremillon and Prof. Max Kohnstamm to consider the possibility of cooperation in the field of development, justice and peace. During the months which followed, cooperation grew rapidly. In April 1968 a jointly organised conference on World Development took place in Beirut, a joint consultation of "Caritas Internationalis" and the WCC Division of "Inter-Church Aid, Refugee and World Service" was organised. Such largescale encounters could not be simply set up by committees, their preparation required joint structures. In December 1968, therefore, the Papal Commission for Justice and Peace Iustitia et Pax and the WCC founded in Geneva the common secretariat of the Committee for Solidarity, Development and Peace (SODEPAX), that cooperated in social ethical matters until its mandate was terminated in 1980 by mutual agreement. It was led by Fr George Dunne S.J. ${ }^{16}$ and was planned in the first instance for a period of only three years (till 1971). The experiential character of its work was crucial. ${ }^{17}$ The work of SODEPAX gave the common witness in this important field the necessary structure and consistency. "The Joint Working Group attached great importance to this cooperation and repeatedly voiced its pleasure at the growing spontaneity with which it was undertaken." 18 Yet problems with the coordination of common projects as well as internal structural changes of the different parent bodies (on the Catholic side Iustitia et Pax had been complemented by Cor Unum, at WCC the Programme Unit on Justice and Service had been reorganised) led to the end of this institution in December $1980 .{ }^{19}$

${ }^{14}$ Cf. The Joint Working Group, "Second Official Report of the Joint Working Group between the Roman Catholic Church and the World Council of Churches" (1967) II,4, Information Service 3 (1967/III), 28-35; 31f.

${ }^{15}$ Cf. Lukas Vischer, "The Activities of the Joint Working Group between the Roman Catholic Church and the World Council of Churches 1965-1969", The Ecumenical Review 22/1 (1970), 36-69; 39: "Alarming reports of the threatening famine in India led to the decision to address a joint appeal to all Christians. In India itself this action had particularly important consequences. It was one of the factors which led to the establishment of AFPRO (Agricultural Food Production), as organization supported by all the Christian Churches in India."

${ }^{16}$ Further members were: Rev. Roy Neehall of the United Presbyterian Church of Trinidad, Brother Christophe von Wachter, a Lutheran member of Taizé, Dr Charles Elliot of the Church of England. The Secretariat was directly responsible to the two co-presidents of SODEPAX, Mgr. Gremillon and Prof. Kohnstamm.

17 Cf. Joseph J. Spae, "SODEPAX: An Ecumenical and Experimental Approach to World Need", The Ecumenical Review 26/1 (1974), 88-99; 89: "The experimental character of SODEPAX is crucial. It remains experimental in many ways: as a search for new and effective methods of collaboration in a common effort to build a decent society; as a dynamic process within a constantly changing world; as a forward-looking endeavour to read, often at its own prophetic risk, the signs of the times; and, finally, as an entity not separate from, let alone opposed to, its constituent bodies, but ever intent upon bringing them, within the limits of its mandate, into deeper mutual involvement and collaboration."

${ }^{18}$ Lukas Vischer, "The Activities of the Joint Working Group between the Roman Catholic Church and the World Council of Churches 1965-1969”, The Ecumenical Review 22/1 (1970), 36-69; 62.

19 Cf. Philip Land S.J., "SODEPAX: An Ecumenical Dialogue", The Ecumenical Review 37/1 (1985) 40-46. Between 1982 and 1989 the Joint Consultative Group for Social Thought and Action took over, yet it proved to be a somewhat weaker instrument. In 1990, during WCC's World Convocation on Justice, Peace and the Integrity 
As this example shows, very quickly the tasks of the JWG had become too manifold. It could not do them all on its own. It had to delegate. Yet it also "had to be sufficiently in the picture about all developments, in order to be able to see and deal with the broad issues in their true context." ${ }^{20}$ Meanwhile the end of the exploratory period of the JWG had been reached.

Looking back at those first five years of enthusiastic experimentation, the work of the JWG centred around three focal points, (1) theological problems arising in the context of the ecumenical movement like the various concepts and approaches to ecumenism or the nature and realisation of dialogue, (2) the renewal of the Church (not just by action, but also by prayer) and (3) practical cooperation in social ethical and international affairs. Nevertheless, a number of open questions concerning its work remained: Is the JWG primarily an institutional link between two centres, WCC and RCC that serve the ecumenical movement? Or is it supposed to directly survey, interpret and promote the ecumenical movement? How can it do so without being really in touch with what is happening ecumenically in various parts of the world? How can it take account of the experience in concrete situations worldwide? This dichotomy of the JWG's task description as an ecumenical agent or a merely institutional link still continues today.

\subsection{Some Crucial Turning Points in the History of the JWG}

Progress after the exploratory phase of the JWG's existence was less spectacular, yet a journey of confidence-building had begun. This journey, however, also knew its ups and downs. Some of the obstacles were due to different perceptions of the ecumenical movement and its goals, to the asymmetry of structures and methods. "Both sides were conscious of the dissimilarities between a council of churches and a church with worldwide extension." ${ }^{21}$ Nevertheless, there was a solid foundation on which to build further steps towards the goal of visible unity. The process itself was irreversible. ${ }^{22}$ This second period of the JWG's existence was characterised by a search for reorganisation (which is the natural WCC reaction after a General Assembly, in that case Uppsala 1968). The time of conciliar ecumenism had arrived and the JWG tried to deal with its ecumenical tasks in their context and to take into consideration that those issues were interrelated at various levels. Consequently the JWG embarked on the broader study of local ecumenism. It "adopted the method of surveying a limited number of specific situations." ${ }^{23}$ In its desire to analyse the underlying difficulties it identified the influence of

of Creation (Seoul, Korea) tensions became apparent "growing out of differences between the WCC and the RCC in their approach to ideological tensions in the world, as well as their differing understandings of and structures for playing a role in international affairs" (Seventh Report, GiA II, 911-934; 931). Nevertheless, a staff member of Iustitia and Pax cooperated on the working group during the WCC Decade to Overcome Violence.

${ }^{20}$ Lukas Vischer, "The Activities of the Joint Working Group between the Roman Catholic Church and the World Council of Churches 1965-1969", The Ecumenical Review 22/1 (1970), 36-69; 64.

${ }^{21}$ Konrad Raiser, "Beyond Collaboration. Perspectives on the Work of the Joint Working Group between the Roman Catholic Church and the World Council of Churches 1972-1982", The Ecumenical Review 35/2 (1983), 179-194; 182.

${ }^{22}$ Cf. Konrad Raiser, "Beyond Collaboration. Perspectives on the Work of the Joint Working Group between the Roman Catholic Church and the World Council of Churches 1972-1982", The Ecumenical Review 35/2 (1983), 179-194; 181.

${ }^{23}$ Konrad Raiser, "Beyond Collaboration. Perspectives on the Work of the Joint Working Group between the 
contextual factors (the so-called non-theological factors like culture, history, social structure) on the development of specific forms of collaboration, while it provided itself a model of inspiration to other, similar groups (on local or national level). The survey of collaborations which the SPCU published in 1975 as Ecumenical Collaboration at the Regional, National and Local Levels ${ }^{24}$ indicated that the ecumenical atmosphere had improved everywhere, but that the situation still varies widely from country to country or local church to local church, and even within a single church.

The following decades of the JWG's history were marked by continued reflection on major ecumenical concerns, an affirmations of mutual commitment to the ecumenical cause and an attempts to intensify relationships between WCC programme units and RCC bodies. Also crises could be managed, like "the strong reaction of the Roman Catholic Church to the consultation on Uniatism (1991) organized by the WCC upon the request of the Eastern Orthodox Churches [...or] the critical attitude of the WCC towards the declaration Dominus Iesus by the Congregation for the Doctrine of the Faith (2000) and the encyclical letter by Pope John Paul II, Ecclesia de Eucharistia (2003)." ${ }^{25}$ These latter documents both had important ecumenical implications. WCC- and RCC-JWG members held discussions on them. The process of dialogue was useful for clarifying some of the misunderstandings. This was in itself an important sign of the JWG's commitment to dialogue. The JWG had meanwhile developed into an important structure of ecumenical collaboration.

The ordinary workflow of the JWG is determined by the mandates of the JWG. As we have seen, in 1966 the emphasis was on the fact that the group has an advisory function:

"Its work is to be more limited: it is intended to examine possibilities in the field of dialogue and cooperation. Moreover, it has no power to take decisions. Its business is the joint study of problems, and thereafter to report to the competent authorities on both sides." 26

In the Fourth Report of 1975 it was felt that the question should now, ten years into its existence, be asked anew: "How should the Roman Catholic Church and the World Council of Churches be related to one another? What areas require primary attention?" 27 - and most importantly: "how can the Roman Catholic Church and the World Council of Churches, without forming one structured fellowship, intensify their joint activities and thereby strengthen the

Roman Catholic Church and the World Council of Churches 1972-1982", The Ecumenical Review 35/2 (1983), 179-194; 184.

${ }^{24}$ Cf. SPCU, "Ecumenical Collaboration at the Regional, National and Local Levels", Information Service 26 (1975/I), 8-32.

25 Aram I, "From Reflection to Reception: Challenges Facing the Roman Catholic Church - WCC Collaboration", The Ecumenical Review 57/4 (2005) 498-505; 500.

26 The Joint Working Group, "First Official Report of the Joint Working Group between the Roman Catholic Church and the World Council of Churches" (1966) no. 1, Information Service 1 (1967/I), 18-33; 18.

27 The Joint Working Group, "Fourth Official Report", Preface,18-23; 18 https://www.oikoumene.org/en/resources/documents/commissions/jwg-rcc-wcc/fourth-report-of-the-joint-worki ng-group (accessed 3 July 2018). 
unity, the common witness and the renewal of the churches?"28 The functions of the JWG were reformulated. It was now asked to discover and assess promising new possibilities for ecumenical development, to stimulate discussions, challenge the parent bodies with propositions to interpret the major streams of ecumenical thought, to exchange information and to establish collaboration between institutions of the RCC and the WCC. ${ }^{29}$ It was still meant to be a consultative group, yet it also was charged with the task to initiate and keep alive discussions and to communicate the findings and recommendations in the best way. This latter point was important, because the JWG needed a greater visibility in order to stimulate local collaboration. The group itself was enlarged to 16 members on each side.

Since 1975 the mandates given by the two parent bodies have all in all been a broad framework for the agenda of the following seven years of the JWG's work. After having revised the mandate, the Fourth Report concluded with the promise "[...] the Joint Working Group looks to the future with a renewed commitment to the one ecumenical movement. It will go on trying faithfully to discern the impulse of the Holy Spirit, given by God as guide on the way ahead." 30

\section{Some Highlights of the Work of the JWG}

\subsection{Theological studies of the JWG: Some examples}

Among the many tasks of the JWG theological study is a key concern, although not an easy task. On the one hand, the JWG should undertake study processes which are or cannot be carried out by other bodies. On the other hand, many doctrinal themes are automatically ruled out, because they are more appropriately dealt with in direct dialogue between the churches. Only themes that are apt to stimulate general ecumenical discussion are eligible. They have to "deal either with a question arising in all discussions between the Roman Catholic Church and other Churches or else with one which confronts all the Churches alike in their debate with the modern world, to which a joint answer might throw new light on old differences." ${ }^{31}$ By studying the topics that qualify for theological study by the JWG this group does not aspire to becoming a second Faith and Order Commission, although there has been at times a close cooperation with Faith and Order. Since there are more than 20 documents, I can present in the context of this article only a very small selection of recurring or really uncommon topics. I limit myself to four.

(A) Common Witness

\footnotetext{
28 Ibid. p. 20.

${ }^{29}$ Cf. ibid. p. 20f.: "There continues to be the need for a forum enabling the Roman Catholic Church and the World Council of Churches to evaluate together the development of the ecumenical movement. [...] The Joint Working Group will primarily aim at discovering and assessing promising new possibilities for ecumenical development. It has the task of stimulating the discussion on the ecumenical movement in being a challenge to the parent bodies by proposing new steps and programmes."

${ }^{30}$ Ibid. p. 23.

${ }^{31}$ Lukas Vischer, "The Activities of the Joint Working Group between the Roman Catholic Church and the World Council of Churches 1965-1969”, The Ecumenical Review 22/1 (1970), 36-69; 47.
} 
The JWG strives to foster a development from "merely doing things together to witnessing together". ${ }^{32}$ To achieve this it has to ask what the attitude of the churches to one another is, and above all what the genuine witness is which the churches have not only a right but the duty to bear to one another and to the world.

Already before and at the New Delhi Assembly in 1961, the WCC had dealt with this topic of common witness and approved the document "Christian Witness, Proselytism and Religious Liberty". ${ }^{33}$ From WCC side "[i]t had now to be shown how far this document could claim validity beyond relationships between the member Churches of the World Council and apply to relations between the Roman Catholic Church and the other Churches." 34 The RCC side could demonstrate how seriously it took "Dignitatis Humanae", the Second Vatican Council's declaration on religious liberty. ${ }^{35}$

In 1971, after some years of intensive discussion, the JWG published the working document "Common Witness and Proselytism". This text "helped to clarify the relations between the missionary calling of each church and the ecumenical responsibility that all churches have for one another." ${ }^{36}$ The text defines 'common witness' and 'proselytism'. Its goal is a "fuller development of, and agreement on, the content of the witness Christians are bound to give to Christ and his Gospel." ${ }^{37}$

Despite these early clarifications this topic remained a perennial issue, an evergreen. In 1982 the JWG published the document "Common Witness", stating that common witness is a way to unity and embodies a will to give visible expression of the already existing unity, "an impelling motive to work for the fullness of visible communion [...] a test and condition for the ecumenical movement." 38 The text considerably increased relations between the Commission of World Mission and Evangelism (CWME) and the RCC.

${ }^{32}$ Konrad Raiser, "Beyond Collaboration. Perspectives on the Work of the Joint Working Group between the Roman Catholic Church and the World Council of Churches1972-1982", The Ecumenical Review 35 (1983/2), 179-194; 184.

${ }^{33}$ Cf. "Christian Witness, Proselytism and Religious Liberty in the Setting of the World Council of Churches: a provisional report", The Ecumenical Review 9/1 (1956), 48-56; cf. also A Documentary History of the Faith and Order Movement, 1927-1963, ed. Lukas Vischer, St Louis, Missouri: The Bethany Press, 1963, $183 \mathrm{ff}$.

${ }^{34}$ Lukas Vischer, "The Activities of the Joint Working Group between the Roman Catholic Church and the World Council of Churches 1965-1969", The Ecumenical Review 22/1 (1970), 36-69; 49.

35 The Second Vatican Council, "Dignitatis Humanae. Declaration on Religious Freedom (7 December 1965)", http://www.vatican.va/archive/hist_councils/ii_vatican_council/documents/vat-ii_decl_19651207_dignitatis-hu manae_en.html (accessed 14 July 2018).

36 Todor Sabev, "The Joint Working Group: Twenty-Five Years in Service of Unity", The Ecumenical Review 42/1 (1980), 17-23; 20.

37 The Joint Working Group, Third Official Report (1970), Appendix II: Common Witness and Proselytism, Information Service 14 (1971/II), 18-23; 18.

38 The Joint Working Group, Fifth Report (1983), GiA II, 821-841; 836. 
In 1998, in its Seventh Report, the JWG felt once more the need to publish on the topic of common witness, religious freedom and proselytism. The document "The Challenge of Proselytism and the Calling to Common Witness" was needed "because of the rise of new situations where people are vulnerable in a variety of ways". ${ }^{39}$ Again the JWG gives definitions of 'common witness', 'civic religious freedom', and 'proselytism'. It writes this document in the hope of "breaking down mistrust, suspicion, misunderstanding or ignorance of the other, where any of these may exist, [... it wants to] encourage persevering effort to seek new ways and means of closer collaboration in evangelization, according to the different circumstances of time, place and culture." ${ }^{40}$ Religious freedom is for the JWG the right for everyone "to pursue the truth and to witness to that truth according to their conscience". ${ }^{41}$ This includes the right to change one's religion. Religious freedom contributes to social harmony and peace. On the other hand, "[p]roselytism can violate or manipulate the right of the individual and can exacerbate tense and delicate relations between communities and thus destabilize societies." 42 Fostering religious freedom is a primary concern of the churches, whereas proselytism "stands in opposition to all ecumenical effort." 43

This study has been one of the basic texts used by CWME for its own 1997 document "Towards Common Witness", ${ }^{44}$ which likewise is a call to adopt responsible relationships in mission and to renounce proselytism (as the subheading states). Moreover, together with the Pontifical Council for Inter-Religious Dialogue and the World Evangelical Alliance the WCC published in 2011 the landmark document "Christian Witness in a Multi-Religious World" 45 which formulates a code of conduct for conversion. This example shows how JWG theological studies deal with a topic that needs to be further developed and adjusted to the needs of the evolving ecumenical movement.

\section{(B) Hierarchy of Truths}

After Pope John Paul II and Willem A. Visser 't Hooft suggested this topic together in 1984, the JWG worked on "The Notion of Hierarchy of Truths". It is the first ecumenical text on this

\footnotetext{
39 The Joint Working Group, Seventh Report (1998), GiA II, 911-934; 927.

40 The Joint Working Group, Seventh Report (1998), Appendix C: "The Challenge of Proselytism and the Calling to Common Witness", GiA II, 891-899; 891.

41 The Joint Working Group, Seventh Report (1998), Appendix C: "The Challenge of Proselytism and the Calling to Common Witness" no. 15, GiA II, 891-899; 894.

42 The Joint Working Group, Seventh Report (1998), Appendix C: "The Challenge of Proselytism and the Calling to Common Witness" no. 16, GiA II, 891-899; 894.

43 The Joint Working Group, Seventh Report (1998), Appendix C: "The Challenge of Proselytism and the Calling to Common Witness" no. 19, GiA II, 891-899; 895.

${ }^{44}$ Commission on World Mission and Evangelism, "'Towards Common Witness, A call to adopt responsible relationships in mission and to renounce proselytism", International Review of Mission 86/3 (1997), 463-473.
}

45 WCC, PCID and World Evangelical Alliance, "Christian Witness in a Multi-religious World", https://www.oikoumene.org/en/resources/documents/wcc-programmes/interreligious-dialogue-and-cooperation/ christian-identity-in-pluralistic-societies/christian-witness-in-a-multi-religious-world (accessed 14 July 2018). 
subject. The drafting of the document was co-organised with Faith and Order. The text aims at understanding the conciliar statement on hierarchy of truths in Unitatis Redintegratio 11. It finds examples in Christian history and draws out the theological and ecumenical implications of this concept, since it "can help to improve mutual understanding and to provide a criterion which would help to distinguish those differences in the understanding of the truths of faith which are areas of conflict from other differences which need not be." 46

\section{(C) Moral Issues}

In its next mandate, the JWG was convinced that doctrinal issues have been discussed a lot, also with the RCC, and that convergences on classical subjects are beginning to form. Yet faith does have ethical consequences, and it was increasingly felt that those issues were not discussed enough. Already the Fifth Report ${ }^{47}$ had stated acute differences about social ethics in and between the churches. Now, in "The Ecumenical Dialogue on Moral Issues - Potential Sources of Common Witness or of Divisions" individual ethics came into focus. The JWG is convinced that "[o]f increasing urgency in the ecumenical movement, in the relationship between the churches called to give common witness, is their need to address those moral issues which all persons face and to communicate moral guidance to church members and to society at large." Therefore, the JWG asks: Why are some moral issues so emotionally and intellectually divisive that often mature dialogue about them is inhibited, even avoided $?^{49}$ - as well as: In what ways do churches formulate ethical principles and decide on specific issues? - or: When does an ethical issue on which Christians disagree become an obstacle to full ecclesial communion? These new divisions within and between the churches on moral issues form urgent challenges because of (1) "the fraying of the moral fabric of many societies [...]; (2) the genuine expectation, both in and beyond the churches, that they together can and should offer moral guidance to their members and to society at large; [and] (3) the need for the churches [...] to be in dialogue with others", ${ }^{50}$ especially people of other world faiths or of secular persuasions.

\section{(D) Ecumenical Dialogue}

Already in 1967 the JWG published a working paper on "Ecumenical Dialogue". Since the Second Vatican Council dialogue had been on everyone's lips and 'relationship in dialogue' had become the watchword for the ecumenical movement. When confronted with this blanket concept, the JWG reflected on what exactly genuine ecumenical dialogue means. Dialogue between Christians is more than simple conversation or mere encounter, it has its own special foundations. It arises from the desire to be more obedient to Christ, is therefore not just an

46 The Joint Working Group, Sixth Report (1990) Appendix B: "The Notion of 'Hierarchy of Truth': An Ecumenical Interpretation", no. 28, GiA II, 876-883; 880.

${ }^{47}$ The Joint Working Group, Fifth Report (1983), GiA II, 821-841; 830.

48 The Joint Working Group, Seventh Report (1998), Appendix B: "The Ecumenical Dialogue on Moral Issues - Potential Sources of Common Witness or of Divisions", no. 1, GiA II, 900-910; 901.

${ }^{49}$ Cf. the questions in the Sixth Report: The Joint Working Group, Sixth Report (1990), GiA II, 842-861; 847848.

50 The Joint Working Group, Seventh Report (1998) no. 5.2, GiA II, 911-934; 926. 
internal Church affair, but aims at common witness. "The dialogue need not be official in order to be real." 51

In 2005 the Eighth Report published a follow-up of the JWG's reflections on ecumenical dialogue. In the last 30 years, a culture of dialogue developed, but also renewed confessionalism and divisions within ecclesial traditions participating in dialogue came to the fore. Therefore, the JWG "explores anew the theological basis of dialogue, elicits a number of principles of dialogue, and develops some theses on the spirituality and practice of ecumenical dialogue". ${ }^{52}$ In this context it also asks: "Are issues of ethics and culture, which have not necessarily been the subject of dialogue, now becoming the sources of division within and between churches?"53 This text on ecumenical dialogue is continued in the Ninth Report by an in depth study on ecumenical reception: "Reception: A Key to Ecumenical Progress". ${ }^{4}$

\subsection{Work in Progress}

The JWG's work in progress, leading on to the Tenth Report, focusses on migrants and peace building. Two theme groups were formed which started working on the two topics during the plenary meeting in Bossey in 2016.

Refugee work has been an ongoing concern for the JWG since its foundation. Certainly, migration has always been part of human history. Yet the current situation of migrants and refugees is often marked by forced migration, the rejection of refugees and racist attitudes in many places. The sheer quantity of migrants and refugees but also the concomitant realities of violence and racism make this phenomenon a significant 'sign of the times' which requires a common response by all churches and their cooperation with others working in the field. Therefore the JWG decided to reflect on the opportunities and challenges for ecumenical cooperation which this current situation creates. The JWG already tried to address the topic of migration in its previous mandate, but could not come to terms with it. Now it shifted its focus on the migrating persons and the impact they have on ecumenical collaboration. The JWG is convinced that all churches are called to strengthen a culture of openness and inclusiveness by welcoming, protecting, integrating and empowering refugees and migrants.

At a time, when in the secular world the prejudice prevails that religion causes or at least contributes to violence, the goal of the peace-building group is to identify the positive contributions which churches can make together to the resolution of conflicts and to the prevention of violence. The JWG asks: What is peace? What threatens peace? What contributes to peace-building? It especially takes into account the role of culture, religion, and dialogue in peace-building. It recognizes the fact that culture, religion and even dialogue can at times be misused to create or support violence and conflict. The JWG is convinced that peace-building

51 The Joint Working Group, "Second Official Report of the Joint Working Group between the Roman Catholic Church and the World Council of Churches" (1967) Appendix: "Ecumenical Dialogue", Information Service 3 (1967/III), 32-35; 34.

52 The Joint Working Group, Eighth Report (2005), GiA III, 500-530; 519.

53 The Joint Working Group, Eighth Report (2005), GiA III, 500-530; 518.

54 The Joint Working Group, Ninth Report (2012), Appendix A: "Reception: A Key to Ecumenical Progress", GiA IV/2, 355-392. 
needs to be undertaken actively and that it requires the constructive involvement of the churches. In order to motivate further engagement it is important to build on already existing successful examples of ecumenical cooperation and to identify new ways in which the churches can contribute to building peace.

On both of these issues the JWG will present recommendations to its parent bodies in its Tenth Report. The aim of these recommendations is to bring about greater unity between all the churches in addressing these areas of vital concern.

\section{Roman Catholic Membership in the WCC}

The JWG was not meant to be a permanent solution to the question of relationship between WCC and RCC but only a provisional one. And it is not the only possible solution. According to the Second Report in 1967, no better solution could as yet be envisaged. The JWG "has proved to be an effective expression of the desire of both parties for an ongoing collaboration and partnership" 55 and, from an historical point of view it did in fact develop into an alternative to membership of the Roman Catholic Church in the World Council of Churches. Yet this was not always as clear as it is today.

In this section I shall follow the considerations that led to asking about RC membership in WCC. ${ }^{56}$ The first important question to address was: Can we speak of one single ecumenical movement? Or is there a Roman Catholic version of ecumenism and a WCC one? At the Second Vatican Council the Council Fathers discussed the principles of ecumenism and as a result of this discussion Unitatis Redintegratio lists the "Catholic principles of ecumenism" (UR 2-4), not the "principles of Catholic ecumenism". Likewise the WCC had to reflect on its own role in the ecumenical movement. I repeat the words of Lukas Vischer who, when writing them in 1970, was research secretary of the WCC Department on Faith and Order, had been a non-Catholic observer at Vatican II and a founding member of the JWG. He was one of the driving forces behind the membership idea on WCC side. He points out that the conviction grew that "the ecumenical movement extends further than the World Council of Churches and it is possible to belong to and to serve that movement without being a member of the Council itself." 57 Moreover, "as long as the Roman Catholic Church accepts the Basis, the World Council of Churches has no option but to leave room for the distinctive Roman Catholic view of the ecumenical movement [...] the World Council is also, by its very nature, a comprehensive fellowship. It is not a federation of non-Roman Catholic Churches but is open in principle to all Churches." ${ }^{18}$ Vischer analyses the consequences of all this:

\footnotetext{
55 PCPCU, "Reflections on the Joint Working Group between the Roman Catholic Church and the World Council of Churches (1965-2005)”, The Ecumenical Review 57/4 (2005) 492-494; 493.

56 For an excellent historical analysis cf. Jan Grootaers, "An Unfinished Agenda. The question of Roman Catholic membership of the World Council of Churches, 1968-1975", The Ecumenical Review 49/3 (1997), 305-347. A valuable study of the JWG would be Catherine E. Clifford, The Joint Working Group between the WCC and the RCC: Historical and Ecclesiological Perspectives, unpublished dissertation, University of Fribourg, 1987.

${ }^{57}$ Lukas Vischer, "The Activities of the Joint Working Group between the Roman Catholic Church and the World Council of Churches 1965-1969", The Ecumenical Review 22/1 (1970), 36-69; 41.

${ }^{58}$ Lukas Vischer, "The Activities of the Joint Working Group between the Roman Catholic Church and the World
} 
"Discussion in the first phase led then to the conclusion that there was no contradiction between the understanding of the ecumenical movement on the two sides. The principles and aims of the Roman Catholic Church and those of the Churches associated together in the World Council of Churches were sufficiently alike to make the extension of relationships and of cooperation not only possible but even mandatory. The second official report made this quite clear. It declared that both the World Council of Churches and the Roman Catholic Church were, in their own way, anxious to serve the one ecumenical movement and that, for the sake of this common aim, there was 'need for constantly more dynamic relations between' them." 59

Membership in a council of churches does not necessarily imply "that each church must regard the other member churches as churches in the true and full sense." ${ }^{60}$ And the JWG is not a permanent structure. However, also the WCC "is a provisional fellowship in which churches are still divided and are therefore not bound together by koinonia in the New Testament sense of the word." 61 Moreover, "[t]he word 'church' is used descriptively. In practice it refers to autonomous ecclesial communities which fulfil certain criteria of stability and size and are able to subscribe to the contents of the Basis"62 of WCC. Therefore, membership in WCC would not necessarily require the Catholic Church to renounce its own ecclesiology. Furthermore, the WCC has not adopted any official conception of unity. This gives the opportunity for a dynamic relation between those concepts existing. Thus, the problems arising from different ecclesiologies and diverging concepts of unity would "have to be a subject of ecumenical discussion". ${ }^{63}$ As far as I can see, this is the phase we are still in.

If we look at the historical development, we notice that already in 1968, at the Fourth Assembly in Uppsala, the first RC speaker ever at a WCC Assembly, Father Roberto Tucci S.J. dealt frankly with the question in his address to the delegates. ${ }^{64}$ Yet would the specific RC witness

Council of Churches 1965-1969", The Ecumenical Review 22/1 (1970), 36-69; 40f.

59 Lukas Vischer, "The Activities of the Joint Working Group between the Roman Catholic Church and the World Council of Churches 1965-1969", The Ecumenical Review 22/1 (1970), 36-69; 42.

${ }^{60}$ Stated by the Central Committee of WCC in 1950 in the so-called Toronto Statement, "The Church, the Churches and the World Council of Churches", IV 4, in: W. A. Visser "t Hooft, The Genesis and Formation of the World Council of Churches, Geneva: WCC Press, 117.

61 The Joint Working Group, "Patterns of Relationship between the RCC and WCC" (1972), The Ecumenical Review 24/3 (1972) 247-288; 254. Cf. also http://www.prounione.urbe.it/dia-int/jwg/doc/e_jwg_patn01.html (accessed on 09/05/2018).

62 The Joint Working Group, "Patterns of Relationship between the RCC and WCC" (1972), The Ecumenical Review 24/3 (1972) 247-288; 254.

63 The Joint Working Group, "Patterns of Relationship between the RCC and WCC" (1972), The Ecumenical Review 24/3 (1972) 247-288; 286.

${ }^{64}$ Cf. The Uppsala Report 1968: Official report of the fourth Assembly of the World Council of Churches, Uppsala, July 4-20, 1968, ed. Norman Goodall, Geneva: WCC Press, 1968, 323-333, where Tucci is reported to have said: "The possibility that the RCC might one day become a member (in the strong sense) of the WCC... is a very delicate question and ... it raises many problems. However, in the view of experts (both Catholic and non-Catholic) the difficulties which might be raised by Roman ecclesiology do not constitute an insuperable 
not be obscured? Would the freedom and authority of non-Roman Catholic churches be harmed? The RCC is a world-wide church, whereas most of the member churches of the WCC are confined to particular geographical areas. How could this go together? Since the debate was opened, the JWG had to investigate the pros and the cons. "Once the Joint Working Group had asserted so emphatically the unity of the ecumenical movement, it was logically bound to add some explanation as to how this unity could be most clearly and effectively expressed." entrusted the answer to this question to a special drafting group, consisting of three WCC and three RCC members.

The decisive setting of the future course happened in May 1969, shortly before the visit of Pope Paul VI to Geneva. The JWG met in Gwatt, Switzerland, and published a brief "Drafted Minute" $^{\prime 66}$ on the topic of RC membership in the WCC. The most obvious solution for a close organic cooperation was Roman Catholic membership in the World Council of Churches. Yet this also brought considerable problems along. If, therefore, this solution were to prove unrealistic and impossible, the JWG would need to come up with other permanent structures of cooperation that might replace this option. ${ }^{67}$ The Minute reckoned with three alternatives, namely "the Roman Catholic Church might enter into membership of the World Council of Churches; a new fellowship of Churches might be created with a different status; coordinated work could be organized between the World Council of Churches and the Roman Catholic Church."68

Pope Paul VI, during his visit to WCC on 10 June 1969, addressed the question of Catholic membership in WCC openly. First he praised the fruitful cooperation between the WCC and the RCC via the $\mathrm{JWG}^{69}$ which in the first place had prompted the question of membership. The

obstacle ... On the other hand, the nonmembership of the Church of Rome in the WCC may have a bad effect on the ecumenical movement as a whole; it may increase the risk of a dangerous tension between non-Catholic and Catholic ecumenism."

65 Lukas Vischer, "The Activities of the Joint Working Group between the Roman Catholic Church and the World Council of Churches 1965-1969", The Ecumenical Review 22/1 (1970), 36-69; 67f.

${ }^{66}$ Cf. The Joint Working Group, "Drafted Minute”, The Ecumenical Review 21/4 (1969), 353-354.

${ }^{67}$ Lukas Vischer, "The Activities of the Joint Working Group between the Roman Catholic Church and the World Council of Churches 1965-1969", The Ecumenical Review 22/1 (1970), 36-69; 67f.

68 The Joint Working Group, "Drafted Minute", The Ecumenical Review 21/4 (1969), 353-354; 354; cf. also Lukas Vischer, "The Activities of the Joint Working Group between the Roman Catholic Church and the World Council of Churches 1965-1969", The Ecumenical Review 22/1 (1970), 36-69; 67.

69 Paul VI, "Speech during Ecumenical Visit to the World Council of Churches (10 June 1969)", http://w2.vatican.va/content/paul-vi/fr/speeches/1969/june/documents/hf_p-vi_spe_19690610_consiglio-ecumen ico-chiese.html (accessed 30 June 2018): "Vous avez aussi mentionné la visite qu'a faite à ce centre, en février 1965, le bien-aimé cardinal Bea, et la mise sur pied d'un groupe mixte de travail. Depuis la création de cette équipe, Nous avons suivi avec intérêt son activité et Nous désirons dire, sans hésitation, combien Nous apprécions le développement de ces relations entre l'Eglise catholique et le Conseil œcuménique, deux organismes très différents par nature, certes, mais dont la collaboration s'est avérée fructueuse." 
Pope's frank answer was that the question of RC membership is not yet ripe for a positive answer. $^{70}$ Thus he encouraged further study of the question and asked for patience.

At the SPCU plenary in 1970 the bishops discussed the question of membership and gave some reasons for their hesitation which led to disappointment on WCC side. Yet the JWG continued to reflect on the possibility of membership, since in May 1969 in Gwatt a study had been demanded about the advantages of different forms of a closer and more permanent association of the RCC with the WCC. Three years later, in 1972, Patterns of Relationship came out. The document is not an officially endorsed report, but was published simply in the name of the JWG. The WCC reading was that "[i]n its study of this question the JWG, while discussing several ways of structuring closer relationships between the RCC and the WCC, clearly expresses a preference for full membership and sees no insuperable obstacles to such a step."71 On the RC side the first alternative, however, was not seen as the only possible solution, since the question of RC membership in WCC is not simply a choice between membership and nonmembership. Ecclesiological and other questions arise, especially questions of a practical kind, like diversity in structures, particularly in relation to the centre of authority in the church, varying traditions of church pronouncements, difference in numerical strength etc. To make a long story short, a preface to Patterns of Relationship signed jointly by Cardinal Willebrands, President of SPCU, and Dr Eugene Carson Blake, General Secretary of WCC, stated that it was not to be expected "in the near future" 72 that the RCC would apply for membership in the WCC.

Why? The RCC would be able to accept the Basis of the WCC. It sees its constitution as a universal fellowship with a universal mission and structure as an essential element of its identity. Another consideration in favour of membership would be that the RCC maintains many close cooperations with WCC in various fields. These relations would involve an unnecessary duplication of structures. If the RCC were only to participate in particular aspects of the work of WCC this multiplication of structures might be avoided in these fields, but the full membership in WCC would just be replaced by a series of inferior memberships. Without full membership the RCC would go on influencing the results without bearing any responsibility connected with these decisions.

\footnotetext{
70 Paul VI, "Speech during Ecumenical Visit to the World Council of Churches (10 June 1969)", http://w2.vatican.va/content/paul-vi/fr/speeches/1969/june/documents/hf_p-vi_spe_19690610_consiglio-ecumen ico-chiese.html (accessed 30 June 2018): "l’Eglise catholique doit-elle devenir membre du Conseil œcuménique? Que pourrions-Nous, en ce moment, répondre à cette question? En toute franchise fraternelle, Nous ne considérons pas que la question de la participation de l'Eglise catholique au Conseil œcuménique soit mûre au point que l'on puisse ou doive donner une réponse positive. La question reste encore dans le domaine de l'hypothèse. Elle comporte de graves implications théologiques et pastorales; elle exige par conséquent des études approfondies, et engage dans un cheminement dont l'honnêteté oblige à reconnaître qu'il pourrait être long et difficile. Mais cela ne Nous empêche pas de vous assurer que Nous regardons vers vous avec grand respect et profonde affection. La volonté qui nous anime et le principe qui nous dirige seront toujours la poursuite pleine d'espérance et de réalisme pastoral de l'unité voulue par le Christ."
}

${ }^{71}$ Konrad Raiser, "Beyond Collaboration. Perspectives on the Work of the Joint Working Group between the Roman Catholic Church and the World Council of Churches 1972-1982", The Ecumenical Review 35 (1983/2), 179-194;182.

72 The Joint Working Group, "Patterns of Relationship between the RCC and WCC" (1972): Preface, The Ecumenical Review 24/3 (1972) 247-288; 249. 
What were the real obstacles? I think the following considerations were decisive: (1) The RCC cannot accept any models of unity that aim at preserving major church-dividing differences. The unity of the church is prefigured in the RCC which possesses all characteristics of the One Church of Jesus Christ (see the famous "subsistit in" of Lumen Gentium). These elements can also be found in other churches, they "have by no means been deprived of significance and importance in the mystery of salvation" (UR 3), but they are impelled towards catholic unity. This determines the model of unity of the RCC. (2) The WCC is a democratically organised fellowship of churches, the RCC is a hierarchically organised church. This causes problems with the way authority is considered and leads to practical differences. The RC structure of decision-making at world and national levels differs widely from the ones of the WCC member churches. (3) Given the principle of proportional representation in WCC, due to its size, the RCC would dominate all decisions in WCC. (4) The concrete political, ethical and social orientation of WCC is quite often not in line with RCC convictions. Apart from this, the Holy See has an international juridical recognition (after all, the Vatican is a state) which in international affairs makes cooperation with the WCC on an equal footing difficult.

Today most likely a fifth reason would have to be added: (5) For the RCC the WCC is no longer the only global player to associate with, but one instrument of the ecumenical movement among others. There was a process between 1991 and 1998 that sought a so-called reconfiguration of the one ecumenical movement. Konrad Raiser had the idea for an "ad hoc ecumenical forum of Christian churches and ecumenical organizations [... which] would also include those Evangelicals and Pentecostals whose communities are growing and have not been involved in the organized ecumenical movement." 73 This led to the founding of the Global Christian Forum. Meanwhile this has given a new, reinforced role to the Christian World Communions. In 1972 Patterns of Relationship still stated that "[t]he WCC is a unique instrument of the ecumenical movement to express and to deepen an as yet incomplete fellowship among the churches. It is not the only expression of the ecumenical movement". ${ }^{74}$ Today it is increasingly questionable whether WCC remains the 'privileged' instrument of the ecumenical movement. ${ }^{75}$

In a letter to the then General Secretary Philip Potter, which followed the Fourth Report (1975) as attachment, Cardinal Willebrands as President of SPCU stated in light of the result of the discussion on RC membership in WCC and the readjusted mandate of JWG: "Given that the Roman Catholic Church will not in the immediate future give expression to it [i.e. ecumenical commitment] by seeking membership in the Council, the role of the Joint Working Group becomes crucial". ${ }^{76}$ The Fifth Report (1983) could even state that meanwhile "[t]here is a more realistic assessment of the differences between the two parent bodies, particularly on the

\footnotetext{
73 The Joint Working Group, "Eighth Report”, GiA III, 500-530; 506.

74 The Joint Working Group, "Patterns of Relationship between the RCC and WCC" (1972), The Ecumenical Review 24/3 (1972) 247-288; 260.

75 Cf. already the question by Lukas Vischer, "A Privileged Instrument of the Ecumenical Movement?", The Ecumenical Review 43/1 (1991), 90-99.

76 Johan Cardinal Willebrands, "Letter from the SPCU to Rev. P. Potter", The Fourth Report (1975) Appendix I, Information Service 30 (1976/I) 23-25; 25.
} 
international level, which still justify the answer given when the possibility of RC membership in the Council was raised in the early 1970s - 'not in the immediate future'. Nor is it a question which is yet ready to be taken up again." 77 The differences of structure are important, and WCC and RCC operate in different ways at world level. Still, the RCC "acknowledges its responsibility within the one ecumenical movement and accepts the challenge of undertaking increased collaboration with the WCC and its member churches." 78 The RC 'no' to full membership did not mean that there would be no further institutionalised links and structures developed. ${ }^{79}$ And part of these structures is currently represented by the JWG. Today, the case of RC membership in WCC seems closed on both sides.

\section{Some Concluding Reflections on Achievements and Challenges - or: What is the JWG and what not?}

The tasks of the JWG remain "[s]tocktaking of the state of ecumenical relations, identifying strengths and weaknesses in actual ecumenical relations, setting priorities with measurable goals, and monitoring progress to determine whether goals have been seriously and consistently pursued". ${ }^{80}$ Furthermore, the JWG is responsible for exchange of information and encouragement of the parent bodies.

Yet, "[d]ocuments of the JWG do not have the authority of bilateral documents between Churches although they have a special status." ${ }^{81}$ From the beginning of the ecumenical movement there were two paradigms, bilateral and multilateral ecumenical dialogue. During the second half of the twentieth century something like a polarisation or 'competition' seems to have developed between bilateral and multilateral dialogues. Undeniably, the concept which sparked off the ecumenical movement was not a bilateral one. "Its aim has been to bring the churches together into a preliminary communion and to advance together, in that communion, towards the goal of full unity. This was the concept behind the founding of the World Council of Churches, in 1948. In the Sixties, however, bilateral conversations between churches of different traditions began to play a bigger role and today the network of these dialogues is such that it has become very difficult to keep track of developments and results in all of them." ${ }^{\prime 82}$ Yet the reason for this increase in bilateral dialogues in the mid- $20^{\text {th }}$ century was not just the Catholic predilection for bilaterals. An important foundation had been laid, when Faith and Order shifted its methodology from a comparative method to a theological approach of

77 The Joint Working Group, "Fifth Report" (1983), GiA II, 821-841; 825.

78 The Joint Working Group, "Fifth Report" (1983), GiA II, 821-841; 826.

79 Since 1978 the RCC seconds a Catholic professor of Biblical Hermeneutics for the Ecumenical Institute in Bossey, and between 1984 and 2013 a Catholic Consultant to CWME was seconded as full time staff member of WCC.

${ }^{80}$ PCPCU, "Reflections on the Joint Working Group between the Roman Catholic Church and the World Council of Churches (1965-2005)", The Ecumenical Review 57/4 (2005) 492-494; 493.

81 The Joint Working Group, "Towards the Renewal of Ecumenism in the $21^{\text {st }}$ Century: The contribution of the JWG, Proposed Working Document", Information Service 188 (2005/IV) 174-177; 177.

${ }^{82}$ Harding Meyer and Lukas Vischer, "General Introduction", in Growth in Agreement I, New York and Geneva: Paulist Press and World Council of Churches 1984, 2-11, 2. 
controversial issues on a common biblical and Christological basis that made convergence and even consensus possible. ${ }^{83}$ Thus alongside and, at times, in tension with the multilateral model of dialogues, which seems to follow the trajectory 'Faith and Order-World Council of Churches-conciliar fellowship-uniting churches', a denomination-oriented model of bilateral dialogues has developed along the axis 'bilateral dialogues-Christian World Communions-reconciled diversity-churches living in mutual recognition', although the two at times also intertwine.

The JWG sits in between these two, because it conducts a bilateral dialogue with a multilateral partner. This brings along major challenges. The main challenge is how to provoke common action and not only common thinking. For the JWG to successfully face this challenge, both parent bodies must be aware of the JWG's work and achievements. When Pope Paul VI visited the WCC on 10 June 1969, he appreciatively mentioned the JWG. When Pope John Paul II visited the WCC on 12 June 1984, he also mentioned with high esteem the JWG. ${ }^{84}$ When Pope Francis visited the WCC on 21 June 2018, he said not a single word about the JWG. ${ }^{85}$ This was a "Black Thursday" for the JWG, since it is vital for its work that the leaders of both parent bodies are aware of its existence and its work.

Of the major challenges which the JWG faces, I would like to list four: (1) It seems difficult these days for the JWG to reach synergetic effects by co-ordinated parallel studies with Faith and Order, like the one on "Hierarchy of Truths" (1990) or concerning the work on the topic "The unity of the church - the goal and the way", with which the JWG was busy in the IV ${ }^{\text {th }}$ phase of its work leading to the Fifth Report (1983). In those days the Faith and Order Commission was asked for help. As a result it published the Faith and Order paper 100 "Towards a Confession of the Common Faith". Instead of a renewed offer of cooperation, we read in the Ninth Report that the JWG should not duplicate the work of Faith and Order. ${ }^{86}$ On

83 This was the case at Lund in 1952, cf. Günther Gaßmann, Art. "Faith and Order" in Nicolas Lossky et al. (ed.), Dictionary of the Ecumenical Movement $2^{\text {nd }}$ ed., Geneva: WCC 2002, 461-463.

84 Pope John Paul II, "Address to WCC during Apostolic visit to Switzerland (12 June 1984)", no. 14 http://w2.vatican.va/content/john-paul-ii/fr/speeches/1984/june/documents/hf_jp-ii_spe_19840612_cons-ecume nico-chiese.html (accessed 4 July 2018): "14. Il y a juste 15 ans, mon prédécesseur le Pape Paul VI vous rendait visite et il se félicitait du développement des relations entre le Conseil œcuménique et l'Eglise catholique. Je tiens à vous dire mon désir, comme je l'ai déjà fait plusieurs fois, que cette collaboration entre nous augmente et s'intensifie partout où c'est possible. Le Groupe Mixte de Travail entre l'Eglise catholique et le Conseil œcuménique des Eglises a une tâche importante à accomplir. Il doit être inventif pour trouver les voies qui permettront d'ores et déjà 'de nous unir consciemment dans la grande mission qui consiste à révéler le Christ au monde' (Ioannis Pauli PP. II, Redemptor Hominis, 11). C'est en faisant ensemble sa vérité que nous manifesterons sa lumière. Cet effort en vue d'un témoignage commun est une des priorités assignées au Groupe Mixte de Travail. Cela demandera un nouvel effort de formation œcuménique et d'approfondissement doctrinal" (My italics).

85 Cf. Pope Francis, Ecumenical Prayer in the Ecumenical Centre, Geneva, 21 June 2018, http://w2.vatican.va/content/francesco/en/events/event.dir.html/content/vaticanevents/en/2018/6/21/ginevra-preg hieraecumenica.html: "Walking, praying and working together: this is the great path that we are called to follow today" - although the motto of the visit would have prompted a reference to the JWG, only Faith and Order, CWME, the Catholic professor at the Bossey Institute were mentioned: cf. id., Address of His Holiness at Ecumenical Meeting at the Ecumenical Centre, Geneva, 21 June 2018, https://w2.vatican.va/content/francesco/en/speeches/2018/june/documents/papa-francesco_20180621_pellegrina ggio-ginevra.html (accessed 26 June 2018).

86 The Joint Working Group, "Ninth Report", GiA IV/2 , 351: "It was underlined that the Joint Working Group 
the other hand, during the $40^{\text {th }}$ anniversary of the JWG Cardinal Kasper had pointed out that "[t]he JWG cannot be a supplementary motor for what 'Faith and Order' should do"87 - and did not achieve, since the JWG published its study on Baptism ${ }^{88}$ years before Faith and Order, ${ }^{89}$ its study on ecclesiology ${ }^{90}$ also years before Faith and Order, ${ }^{91}$ its study on moral issues ${ }^{92}$ even before Faith and Order began its debate about it... ${ }^{93}$

(2) It proves increasingly difficult for the JWG to give valuable pastoral reflection (either by asking a specialised body for a particular contribution or) by organising a study on its own. On the one hand, during the current mandate the factual input from external experts is very feeble; on the other hand, taking the huge variety of contexts into account, it is not possible for a group of 20 people to address them all adequately. Closely connected to this is the next challenge.

(3) The reception of JWG reports and the implementation of its recommendations are less than meagre. While engaging in studies is important, the results of these studies should reach the parent bodies and through them the grassroots. Here I see one of the main responsibilities of the parent bodies. Since the JWG is small, the bodies it serves have a broader responsibility. An improvement in two-way communication between the JWG and its parent bodies is indispensable. ${ }^{94}$ The parent bodies should seriously take into account how to implement the recommendations of the JWG and the JWG should be kept abreast of the process of implementation and should receive feedback from the parent bodies about the practical

should not duplicate the work of the Faith and Order Commission."

${ }^{87}$ Walter Kasper, "The Ecumenical Movement in the $21^{\text {st }}$ Century - A Contribution from the PCPCU", The Ecumenical Review 57/4 (2005) 505-515; 510.

88 The Joint Working Group, "Ecclesiological and Ecumenical Implications of a Common Baptism (2005)", GiA III, 559-586.

${ }^{89}$ The Faith and Order Commission, "One Baptism: Towards Mutual Recognition. A study text. F\&O paper 210, Geneva 2011", GiA IV/2, 241-264.

90 The Joint Working Group, "The Church: Local and Universal (1990)", GiA II, 862-875.

91 The Faith and Order Commission, "The Church: Towards a Common Vision. F\&O paper 214, Geneva 2013", GiA IV/2, 265-298.

92 The Joint Working Group, "The Ecumenical Dialogue on Moral Issues: Potential Sources of Common Witness or of Divisions (1995)", GiA II, 900-910.

93 The Faith and Order Commission, "Moral Discernment in the Churches. F\&O paper 215, Geneva 2013", GiA IV/2, 299-328.

94 This seems to be a perennial problem. Cf. already the complaint in 1970 by Lukas Vischer, "The Activities of the Joint Working Group between the Roman Catholic Church and the World Council of Churches 1965-1969", The Ecumenical Review 22/1 (1970), 36-69; 65: "The results of the work are too little known in the Churches; but, above all, the Joint Working Group does not receive from the Churches expressions of opinion which would enrich and assist its discussions. Of course, the official reports are published, and, since the members of the Group are drawn from various parts of the world, they are aware of the various situations. But these contacts are not yet adequate. There needs to be a systematic development of exchange with the Churches, in particular with the many bodies which have responsibility at the national level and which have in part been formed on the pattern of the Joint Working Group." 
feasibility of its suggestions. This communication circle would facilitate the work of the JWG highly. For, although the JWG always makes a point of visiting the National Council of Churches in each country where it meets in order to foster contacts with the grassroots, this is not enough and can only marginally influence the JWG's work.

(4) The world is changing rapidly. The ecumenical horizon is changing just as fast. These changes affect the parent bodies and therefore have an impact on the JWG. How can the JWG find ways of responding to or - what would be even more desirable - proactively influencing these changes? Since its foundation in 1965 it still functions more or less in the same way, while the context has constantly been changing. The style of the JWG should be kept flexible and adjustable to a range of changing needs. It was hoped that a distinction between JWG members and external experts or consultants who are invited for special questions would allow more flexibility and fresh input. Yet during the current mandate this does not work. The parent bodies or the JWG itself should urgently come up with alternative solutions to preserve its adaptability to the current ecumenical developments.

The JWG is one longstanding, though preliminary instrument of the ecumenical movement, but should remain an effective instrument. For the RCC and WCC carry on their ecumenical witness on the basis of different ecclesiological assumptions. ${ }^{95}$ "Because our vision of unity is based on our ecclesiological self-understanding, we have a different understanding of visible unity [...] even within the WCC, churches differ considerably in their perception of unity". ${ }^{96}$ Thus, there continues to be a dire need for a forum to evaluate ecumenical developments between WCC and RCC jointly, while assessing the situation of the ecumenical movement and discovering new ways of collaboration.

Moreover, as a reminder that dialogue and action belong together, the JWG has an important contribution to make in the renewal of ecumenism in the $21^{\text {st }}$ century, especially in identifying further common ground between the two parent bodies and offering them a common vision.

\footnotetext{
95 Cf. the Faith and Order Commission, "The Church: Towards a Common Vision", GiA IV/2, 265-298.

96 Aram I, "From Reflection to Reception: Challenges Facing the Roman Catholic Church -WCC Collaboration", The Ecumenical Review 57/4 (2005) 498-505; 500.
} 